\title{
PENGARUH ADVERSITY QUOTIENT DAN KOMPETENSI TERHADAP KINERJA KARYAWAN PT. ASKES (PERSERO) PALU
}

\author{
Firza Umar Salim, S.E., M.M. \\ (Dosen Fakultas Ekonomi Universitas Alkhairaat)
}

\begin{abstract}
ABSTRAK
Penelitian ini bertujuan untuk mengetahui apakah variabel adversity quotient dan kompetensi secara serempak berpengaruh signifikan terhadap kinerja karyawan PT. Askes (Persero) Palu, pengaruh variabel adversity quotient terhadap kinerja karyawan PT. Askes (Persero) Palu dan pengaruh variabel kompetensi terhadap kinerja karyawan PT. Askes (Persero) Palu. Populasi dalam penelitian ini berjumlah 54 karyawan. Penarikan sampel menggunakan rumus Slovin sehingga hasil yang diperoleh sejumlah 35 responden. Hasil penelitian menunjukkan bahwa: hasil perhitungan diperoleh $\mathrm{F}$ sig pada taraf nyata $\alpha=$ 0,05 maka diperoleh Sig F (0.000) < 0,05. Dengan demikian dapat dinyatakan bahwa secara bersama-sama (serempak) variabel bebas mempunyai pengaruh yang signifikan terhadap variabel tidak bebasnya; adversity quotient berpengaruh signifikan terhadap kinerja dengan nilai sig 0.000 ; dan kompetensi berpengaruh signifikan terhadap kinerja dengan nilai sig 0.000 . Hubungan kedua variabel adversity quotient dan kompetensi yang diamati dalam penelitian ini terhadap kinerja karyawan PT. Askes (Persero) Palu sebesar $88,5 \%$. Adapun kelebihannya sebesar $11,5 \%$ diakibatkan oleh variabel lain di luar variabel bebas yang diamati, diantaranya kepemimpinan, kompensasi dll.
\end{abstract}

Kata Kunci: Adversity Quotient, Kompetensi, Kinerja.

\section{LATAR BELAKANG}

Pada era seperti ini dimana persaingan yang sangat ketat terjadi tidak hanya pada perusahaan sejenis, namun terjadi pada perusahaan yang memiliki keterkaitan secara langsung maupun tidak langsung. Keadaan ini membentuk pola pikir perusahaan untuk mencegah daripada melakukan perbaikan ketika perusahan tersebut sudah mulai tersingkir dari arena persaingan tersebut. Menurut (Umar A, 2019) Tujuan didirikannya perusahaan adalah untuk mencari keuntungan yang layak untuk memelihara dan mempertahankan kelangsungan hidup perusahaan serta mengembangkan usaha. Banyak cara yang dilakukan perusahaan agar tetap berada dalam arena yang kompeten, dimulai dari memodifikasi barang sampai pada menjadikan manusia sebagai aset perusahaan. Alasan tersebut dikarenakan kebutuhan tenaga-tenaga terampil di berbagai bidang sudah merupakan tuntutan dunia global yang tidak dapat ditunda, karena itu setiap perusahaan harus menyadari pentingnya kemampuan dalam membuat rencana pengembangan sumber daya manusia yang berkualitas.

Menurut (Azis, 2019) Kelangsungan sebuah organisasi tak lepas pada kinerja pegawai yang baik. Hal yang tak dapat dipungkiri bahwa sumber daya manusia adalah salah satu aset yang memegang kunci penting bagi perusahaan dalam mencapai visi perusahaan baik secara kualitas maupun kuantitas. Sebuah kewajaran apabila dalam suatu perusahaan dihuni oleh sumber daya manusia yang memiliki pengetahuan, kemampuan sampai pada keahlian yang sangat sesuai dengan perusahaan tersebut, maka dapat diprediksi perusahaan tersebut akan meraih kesuksesan pada bidang yang digeluti perusahaan tersebut dan begitupula sebaliknya.

PT. Askes (Persero) Palu merupakan salah satu Badan Usaha Milik Negara (BUMN) yang bergerak di bidang jasa penyelenggaraan asuransi kesehatan bagi Pegawai Negeri Sipil (PNS) dan bukan PNS. Dalam menjalankan kegiatannya sebagai perusahaan asuransi, PT. Askes (Persero) Palu memiliki visi yang diharapkan dapat memberikan gambaran masa 
depan yang realistik dan dapat dicapai, memiliki arah, mudah dimengerti dan fleksibel sehingga menjadi Spesialis Asuransi Kesehatan dan Jaminan Pemeliharaan Kesehatan dan Market Leader di Sulawesi Tengah. Untuk mencapai visi tersebut maka PT. Askes (Persero) Palu memiliki misi sebagai berikut :

1. Menyelenggarakan jaminan pemeliharaan kesehatan yang bersifat sosial berdasarkan managed cure untuk kemanfaatan maksimum bagi peserta wajib.

2. Menyelenggarakan asuransi kesehatan yang bersifat komersial bagi masyarakat berpenghasilan tetap, terutama menengah ke atas berdasarkan managed cure dan indemnity untuk manfaat bagi stakeholders.

Visi dan misi tersebut dapat tercapai apabila sumber daya manusia di dalamnya bekerja dengan baik, melakukan tugas-tugas dengan tepat dan cermat sampai pada menjalin hubungan secara horizontal maupun vertikal. Hal ini tentunya harus dilakukan oleh semua komponen masyarakat PT. Askes (Persero) Palu dimulai dari manajemen level atas (top manajemen) sampai manajemen level bawah (bottom management). Untuk mencapai hal-hal diatas maka perlulah dibentuk sumber daya manusia yang memiliki kinerja terstandarisasi dengan kebutuhan perusahaan, pelanggan sampai pada kebutuhan zaman.

Sumber daya manusia yang baik adalah manusia yang dapat mengelola diri sendiri dengan cara yang cerdas, tepat dan cepat (Stoltz, 2000; 22). Kinerja seseorang takkan dapat dicapai apabila manusia tidak dapat mengelola diri sendiri terlebih dahulu. Manusia yang dapat mengelola diri sendiri dengan cara-cara yang tepat dikatakan dengan manusia yang memiliki kondisi internal yang baik.

PT. Askes (Persero) Palu sebagai penyedia jasa asuransi kesehatan bagi masyarakat yang jumlahnya sangat banyak seharusnya memperhatikan potensi karyawannya (tidak hanya karyawan tetap melainkan karyawan tidak tetap), karena yang menjadi penggerak PT. Askes (Persero) Palu adalah manusia-manusia di dalamnya. Apabila perlakuan kepada karyawan tidak didistribusikan secara adil, maka pastilah akan membuat kinerja karyawan tidak merata. Kinerja karyawan yang buruk tentunya akan menimbulkan sebuah masalah bagi PT. Askes (Persero) Palu sendiri.
Untuk menghadapi sebuah masalah, manajemen PT. Askes (Persero) Palu seharusnya sadar bahwa karyawan tidak cukup menggunakan kecerdasan intelektualnya saja akan tetapi karyawan perlu dibekali dengan mental yang kuat dalam menghadapi masalah. Salah satu cara untuk melatih karyawan-karyawan PT. Askes (Persero) Palu dalam menghadapi masalah adalah dengan menggunakan kecerdasan selain kecerdasan intelektual yang berada dalam diri karyawan tersebut yaitu Adversity Quotient. Adversity Quotient menurut Stoltz (2000; 90) merupakan suatu penilaian yang mengukur bagaimana respon seseorang dalam menghadapai masalah atau kesulitan untuk dapat diberdayakan menjadi peluang. Adversity Quotient (AQ) menjadi demikian penting dalam menentukan kesuksesan hidup karena AQ akan menunjukkan seberapa baik seseorang dapat menghadapi kesulitan dan mengatasinya. Kecerdasan ini merupakan salah satu dari kecerdasan emosi yang membuat seseorang dapat bertahan dalam menghadapi masalah yang dihadapi.

Selain Adversity Quotient (AQ) salah satu variabel yang juga mempengaruhi kinerja karyawan adalah kompetensi karyawan. Upaya awal untuk menentukan kualitas yang efektif didasarkan pada sejumlah sifat-sifat kepribadian dan keterampilan. Ini adalah suatu pendekatan model input, yang fokus pada keterampilan yang dibutuhkan untuk mengerjakan suatu pekerjaan. Keterampilan-keterampilan ini adalah kompetensi dan mencerminkan kemampuan potensial untuk melakukan sesuatu. Kompetensi mutlak dibutuhkan, khususnya bagi Pegawai Negeri Sipil sebagai pengabdi pada lembaga pemerintahan. Faktor lain yang mendukung wujud kompetensi adalah kedisiplinan pegawai yang didukung oleh lingkungan kerja yang baik, sehingga dapat tercipta suatu kinerja yang efektif dan efisien.

Sinamo (Kaco, 2006; 42) mengatakan bahwa kompetensi merupakan strategi yang diarahkan untuk meningkatkan kualitas layanan apa saja kepada masyarakat demi mencapai harapan mereka yaitu kepuasan. Untuk itulah dalam Peraturan Pemerintah Nomor 101 Tahun 2000 ditekankan empat jenis kompetensi yang harus dimiliki oleh pegawai yaitu kompetensi tekhis (technical competence), kompetensi manajerial (manajerial competence), kompetensi sosial (social competence), serta kompetensi intelektual/ strategik (intelektual/ strategic comptence). 
Indikasi rendahnya kompetensi juga dapat dilihat dari seringnya terjadi keterlambatan dalam penyelesaian atau pengurusan suatu berkas, ada sebagian oknum pegawai yang tidak berada ditempat kerjanya pada saat jam kerja dan kurang cepatnya yang diberikan karyawan PT. Askes (Persero) Palu. Dengan melihat beberapa fenomena diatas, maka peneliti melakukan penelitian dan menuangkannya ke dalam skripsi dengan judul "Pengaruh Adversity Quotient dan Kompetensi terhadap Kinerja Karyawan PT. Askes (Persero) Palu".

Rumusan Masalah

Berdasarkan uraian latar belakang di atas, maka rumusan masalah dalam penelitian ini adalah :

1. Apakah adversity quotient dan kompetensi secara serempak berpengaruh signifikan terhadap kinerja karyawan PT. Askes (Persero) Palu?

2. Apakah adversity quotient berpengaruh positif dan signifikan terhadap kinerja karyawan PT. Askes (Persero) Palu?

3. Apakah kompetensi berpengaruh positif dan signifikan terhadap kinerja karyawan PT. Askes (Persero) Palu?

\section{Tujuan Penelitian}

Berdasarkan latar belakang dan rumusan masalah, maka tujuan penelitian ini adalah :

1. Untuk mengetahui apakah variabel adversity quotient dan kompetensi secara serempak berpengaruh signifikan terhadap kinerja karyawan PT. Askes (Persero) Palu.

2. Untuk mengetahui apakah variabel adversity quotient berpengaruh signifikan terhadap kinerja karyawan PT. Askes (Persero) Palu.

3. Untuk mengetahui apakah variabel kompetensi berpengaruh signifikan terhadap kinerja karyawan PT. Askes (Persero) Palu.

\section{Manfaat Penelitian}

Manfaat yang ingin dicapai dari penelitian ini adalah :

1. Sebagai masukan bagi PT. Askes (Persero) Palu dalam menentukan kebijakan peningkatan hasil kerja pegawai dan manajemen sumber daya manusia.

2. Sebagai bahan referensi untuk menambah informasi penelitian selanjutnya, terutama yang berkaitan dengan adversity quotient, kompetensi dan kinerja.
3. Merupakan sumbangan teoritis dalam bidang penelitian sumber daya manusia khususnya mengenai adversity quotient, kompetensi dan kinerja.

Hipotesis

Dari hasil studi atas berbagai teori yang berkaitan dengan rumusan masalah yang dilanjutkan dengan menyusun tujuan penelitian dan kerangka pemikiran, maka diajukan hipotesis sebagai berikut :

1. Adversity quotient dan kompetensi secara serempak berpengaruh signifikan terhadap kinerja karyawan PT. Askes (Persero) Palu.

2. Adversity quotient berpengaruh positif dan signifikan terhadap kinerja karyawan PT. Askes (Persero) Palu.

3. Kompetensi berpengaruh positif dan signifikan terhadap kinerja karyawan PT. Askes (Persero) Palu.

\section{METODE PENILITIAN}

\section{Jenis Penelitian}

Penelitian ini dilakukan untuk memperoleh gambaran tentang pengaruh variabel independen yang terdiri dari adversity quotient dan kompetensi terhadap kinerja karyawan di PT. Askes (Persero) Palu, sehingga jenis penelitian ini adalah deskriptif kausal yang dilaksanakan melalui pengumpulan data dilapangan pada karyawan yang bekerja di PT. Askes (Persero) Palu.

\section{Lokasi dan Waktu Penelitian}

Adapun yang menjadi lokasi penelitian ini pada kantor PT. Askes (Persero) Palu Jl. Muh. Yamin Kota Palu. Waktu penelitian dilakukan pada bulan Februari sampai Mei 2019 dengan jangka waktu yang 4 bulan dengan responden adalah karyawan yang bekerja di PT. Askes (Persero) Palu Sulawesi Tengah

\section{Populasi, Sampel dan Teknik Penarikan Sampel \\ Populasi}

Populasi dalam penelitian ini adalah para karyawan di PT. Askes (Persero) Palu. Jumlah karyawan di PT. Askes (Persero) Palu sebanyak 54 karyawan.

Sampel

Pengambilan sampel ini harus dilakukan karena jumlah populasi sebanyak 54 adalah relatif besar dan tentunya akan membutuhkan waktu, biaya dan energi yang tidak sedikit jika keseluruhan populasi tersebut harus diteliti. 
Penentuan jumlah sampel menggunakan rumus Slovin (Umar, $2002 ; 78$ ) sebagai berikut :

$$
\begin{aligned}
& n=\frac{N}{1+N e^{2}} \\
& \text { Keterangan; } \\
& n \quad=\text { Ukuran sampel } \\
& \mathrm{N} \quad=\text { Ukuran populasi } \\
& e \quad=\text { Nilai kritis (batas ketelitian) } \\
& \text { yang diinginkan (persen kelonggaran } \\
& \text { ketidaktelitian karena kesalahan pengambilan }
\end{aligned}
$$
penelitian ini, dengan batas ketelitian $10 \%$ adalah

$$
n=\frac{N}{1+N e^{2}} \quad=\frac{54}{1+(54)(0.1)^{2}}=
$$$$
35.1 \approx 35 \text {. }
$$

Jumlah 35 (tiga puluh lima) sampel tersebut sudah melebihi dari syarat kecukupan data untuk menganalisis fenomena dengan menggunakan analisis regresi yaitu sebesar 30 . Berdasarkan hal tersebut, penelitian ini mengambil 35 unit sampel dari karyawan di PT. Askes (Persero) Palu.

\section{Teknik Penarikan Sampel}

Unit sampling dalam Populasi penelitian ini adalah karyawan di PT. Askes tidak terlalu besar maka teknik penarikan sampel yang digunakan adalah simple random sampling. Simple random sampling dinyatakan simple (sederhana) karena pengambilan sampel anggota populasi dilakukan secara acak tanpa memperhatikan strata yang ada dalam populasi itu (Sugiyono, 2001; 78).

\section{Jenis dan Sumber Data}

Jenis data yang digunakan dalam penelitian ini adalah :

1. Data kualitatif

Data yang bersifat tidak tersutruktur, sehingga variasi data dari sumbernya bisa beragam. Hal ini disebabkan para responden dalam penelitian ini diberi kebebasan dalam mengutarakan pendapat. Data kualitatif dapat dinyatakan dalam bentuk kata, kalimat atau gambar.

2. Data kuantitatif

Mendasarkan penelitian pada perhitunganperhitungan matematis yang membrikan gambaran atas fenomena kasus yang diajukan dalam penelitian. Data angka yang dihasilkan menjadi acuan atau parameter tingkat atau level yang telah ditentukan sebelumnya.

Sumber data yang digunakan dalam penelitian ini adalah :

1. Data Primer

Data Primer, yaitu data yang penulis peroleh secara langsung dari sumbernya melalui observasi, maupun daftar pertanyaan. Data ini diperoleh dari responden melalui tanggapan karyawan pada Bidang PT. Askes (Persero) Palu terhadap kuesioner yang diedarkan.

2. Data Sekunder

Data Sekunder, yaitu data penunjang yang berhubungan dengan penelitian yang bersumber dari data primer yang telah diolah lebih lanjut dan disajikan baik oleh pihak pengumpul data primer atau oleh pihak lain.

\section{Metode Pengumpulan Data}

Metode pengumpulan data yang digunakan untuk memperoleh data akurat yang diperlukan dalam penelitian ini adalah :

1. Observasi

Yakni melakukan pengamatan langsung mengenai aktivitas kerja para karyawan pada Bidang PT. Askes (Persero) Palu khususnya sikap dan perilaku mereka saat berinteraksi langsung dengan masyarakat.

2. Kuesioner

Yaitu usaha untuk mengumpulkan informasi dengan mengajukan sejumlah pernyataan secara tertulis kepada responden untuk dijawab secara tertulis. Pernyataan dirancang sedemikian rupa sehingga memudahkan responden untuk menjawab.

3. Dokumentasi

Yaitu dengan cara mencatat atau foto copy data yang telah dikumpulkan (didokumentasikan) oleh PT. Askes (Persero) Palu yang berkaitan dengan objek penelitian ini.

4. Wawancara

Dalam metode ini penulis melakukan tanya jawab dengan karyawan PT. Askes (Persero) Palu.

\section{Uji Validitas}

Pengujian validitas dalam penelitian ini dimaksudkan untuk mengetahui apakah tiap butir dalam instrument yang digunakan sudah dapat mengukur faktor kepemimpinan, kompetensi dan 
kinerja. Jika $r$ (korelasi), dengan item tersebut valid. Besarnya $\mathrm{r}$ tiap butir pertanyaan dapat dilihat dari SPSS pada kolom Corrected Items Correlation). Kriteria uji validitas secara singkat (rule of tumb) adalah 0,3. Jika Korelasi sudah lebih besar dari 0,3 , pertanyaan yang dibuat dikatagorikan valid/shahih (Setiaji, 2004; 11). Berdasarkan hasil analisis dengan bantuan program SPSS 16.00 telah dilakukan melalui pengujian statistik terhadap variabel adversity quotient (X1) dan kompetensi (X2) terhadap kinerja karyawan PT. Askes (Persero) Palu secara keseluruhan item pernyataan dinyatakan valid sebagaimana terlampir dalam lampiran.

\section{Uji Reliabilitas}

Reliabilitas menyangkut masalah kepercayaan terhadap ketepatan atau kehandalan alat ukur. Diharapkan alat ukur yang digunakan pada penelitian ini dapat bernilai demikian, karena alat ukur yang mantap dengan sendirinya dapat diandalkan (dependability), hasil pengukurannya bisa diramalkan (predictability) dan dapat menunjukkan tingkat ketepatan (Rangkuti, 2009; 44).

Tabel 1 Hasil Pengujian Reliabilitas Variabel Penelitian

\begin{tabular}{|c|c|c|}
\hline Variabel & $\begin{array}{c}\text { Alpha } \\
\text { Cronbac } \\
h\end{array}$ & $\begin{array}{c}\text { Keteranga } \\
\mathrm{n}\end{array}$ \\
\hline $\begin{array}{c}\text { Adversity } \\
\text { Quotient } \\
\left(\mathrm{X}_{1}\right)\end{array}$ & 0.831 & Reliable \\
\hline $\begin{array}{c}\text { Kompetens } \\
\mathrm{i}\left(\mathrm{X}_{2}\right)\end{array}$ & 0.859 & Reliable \\
\hline Kinerja (Y) & 0.836 & Reliable \\
\hline
\end{tabular}

Teknik Analisis Data

\section{Pengujian Asumsi Klasik}

Untuk menentukan ketepatan model regresi perlu dilakukan pengujian atas beberapa asumsi klasik yang mendasari model regresi sebagai berikut;

1. Multikolinearitas

Uji ini dimaksudkan untuk mengetahui apakah diantara variabel bebas (independent) tidak saling berkorelasi atau tidak terdapat hubungan yang signifikan antara variabel. Uji multikolonieritas bertujuan untuk menguji apakah model regresi ditemukan adanya korelasi antar variabel bebas atau independen. Model regresi yang baik seharusnya tidak terjadi korelasi diantara variabel independen
(Ghozali, 2005; 105). Adanya multikolinearitas dapat dilihat dari tolerance value atau Variance Inflation Factor (VIF). Nilai cut off yang umum dipakai untuk menunjukkan adanya multikoleniaritas adalah nilai tolerance $<0,10$ atau VIF $>10$ (Ghozali, 2005; 105). Hasil uji multikolinearitas dengan menggunakan VIF dan tolerance seperti pada tabel berikut:

Tabel 2 Hasil Pengujian Multikolinearitas

\begin{tabular}{|c|c|c|c|}
\hline \multirow{2}{*}{ No } & \multirow{2}{*}{ Variabel } & \multicolumn{2}{|c|}{ Collinearity Statistics } \\
\cline { 3 - 4 } & & VIF & Tolerance \\
\hline 1 & Adversity Quotient $\left(\mathrm{X}_{1}\right)$ & 1.179 & 0.848 \\
\hline 2 & Kompetensi $\left(\mathrm{X}_{2}\right)$ & 1.179 & 0.848 \\
\hline
\end{tabular}

2. Heterokedastisitas

Uji heterokedatisitas bertujuan menguji apakah dalam model regresi terjadi ketidaksamaan variance dari residual satu pengamatan ke pengamatan yang lain (Ghozali, 2005; 106). Jika varians dari residual satu pengamatan ke pengamatan lain tetap, maka disebut homoskedastisitas dan jika berbeda disebut heteroskedastisitas.

Cara yang digunakan untuk mendeteksi ada atau tidaknya heteroskedastisitas dalam penelitian ini, dengan melihat grafik plot antara nilai prediksi variabel terikat (dependen) yaitu ZPRED dengan residualnya yaitu SRESID.

Dasar analisis yang digunakan untuk mendeteksi heteroskedastisitas adalah sebagai berikut;

a. Jika ada pola tertentu, seperti titik-titik yang ada membentuk pola tertentu yang teratur (bergelombang, melebar kemudian menyempit), maka mengindikasikan telah terjadi heteroskedastisitas.

b. Jika tidak ada pola yang jelas, serta titiktitik menyebar diatas dan dibawah angka 0 pada sumbu $\mathrm{Y}$, maka tidak terjadi heteroskedastisitas.

Hasil uji heterokedastisitas dari model regresi yang terbentuk tersaji pada gambar berikut: 


\section{Gambar 1 Hasil Pengujian Heteroskedastisitas}

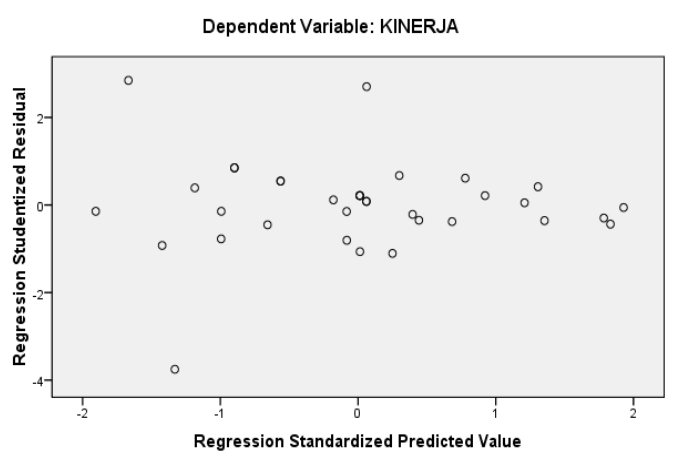

Berdasarkan gambar di atas terlihat titik-titik menyebar secara acak, tidak membentuk sebuah pola tertentu yang jelas, serta tersebar baik di atas maupun dibawah angka 0 pada sumbu Y. Hal ini memberi makna bahwa persamaan regresi memenuhi asumsi heteroskedastisitas.

3. Normalitas

Uji normalitas bertujuan untuk menguji apakah dalam model regresi, variabel pengganggu atau residual memiliki distribusi normal (Ghozali, 2005; 110). Sedangkan dasar pengambilan keputusan dalam deteksi normalitas;

a. Jika data menyebar disekitar garis diagonal dan mengikuti arah garis diagonal, maka model regresi memenuhi asumsi normalitas.

b. Jika data menyebar jauh dari garis diagonal dan atau tidak mengikuti arah garis diagonal, maka model regresi tidak memenuhi asumsi normalitas.

Dengan menggunakan bantuan program statistik hasil uji normalitas data pada penelitian ini dapat dilihat pada grafik (gambar) di bawah ini:

Gambar 2 Hasil Pengujian Normalitas
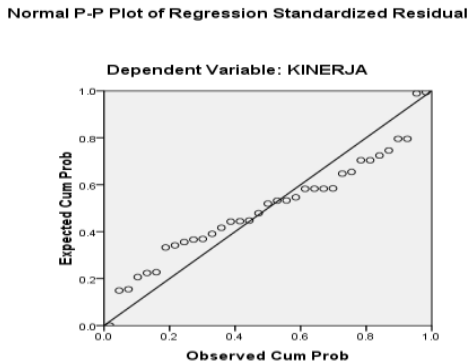

Pada gambar tersebut memperlihatkan bahwa sebaran data mengikuti garis diagonal. Berdasarkan hal tersebut, maka dapat disimpulkan bahwa data yang digunakan dalam analisis regresi ini terdistribusi dengan normal.

\section{HASIL DAN PEMBAHASAN}

\section{Hasil Pengujian Regresi Linear Berganda}

Dalam konteks penelitian ini regresi linear berganda digunakan untuk mengukur pengaruh adversity quotient (X1), dan kompetensi (X2) terhadap kinerja (Y) karyawan PT. Askes (Persero) Palu.

Sesuai hasil analisis Regresi Linear Berganda dengan menggunakan bantuan komputer SPSS For Wind Release 16.0 diperoleh hasil-hasil penelitian dari 35 orang responden dengan dugaan pengaruh kedua variabel independen adversity quotient (X1), dan kompetensi (X2) terhadap kinerja (Y) karyawan PT. Askes (Persero) Palu dapat diketahui hasil perhitungan sebagai berikut;

Tabel Hasil Perhitungan Uji Regresi Linear Berganda

\begin{tabular}{|l|c|c|c|c|}
\hline \multirow{2}{*}{ Variabel } & \multicolumn{2}{|c|}{$\begin{array}{c}\text { Unstandardized } \\
\text { Coefficients }\end{array}$} & \multirow{2}{*}{$t$} & \multirow{2}{*}{ Sig } \\
\cline { 2 - 5 } & $\mathrm{B}$ & $\begin{array}{c}\text { Std. } \\
\text { Error }\end{array}$ & & \\
\hline Constanta & -4.733 & 2.977 & -1.590 & 0.122 \\
\hline Adversity Quotient & 0.633 & 0.056 & 11.233 & 0.000 \\
\hline Kompetensi & 0.421 & 0.074 & 5.721 & 0.000 \\
\hline R & $; 0.941$ & \multicolumn{4}{|c|}{ F Hitung $; 123.212$} \\
R Square & $; 0.885$ & Sig F & $; 0.000$ \\
\hline
\end{tabular}

Model regresi yang diperoleh dari tabel diatas adalah;

$$
\mathrm{Y}=-\mathbf{4 . 7 3 3}+\mathbf{0 . 6 3 3 X} 1+\mathbf{0 . 4 2 1 X 2}
$$

Persamaan diatas menunjukkan, variabel independen yang dianalisis berupa variabel adversity quotient (X1), dan kompetensi (X2) memberi pengaruh terhadap variabel kinerja (Y).

Dari persamaan di atas dapat dijelaskan;

1. Untuk nilai constanta sebesar -4.733 berarti

kinerja karyawan PT. Askes (Persero) Palu sebelum adanya variabel independen adalah sebesar -4.733 .

2. Adversity Quotient (X1) dengan koefisien regresi 0.633 ini berarti terjadi pengaruh yang positif antara adversity quotient dan kinerja karyawan PT. Askes (Persero) Palu. Artinya 
jika sikap adversity quotient yang dimiliki karyawan PT. Askes (Persero) Palu meningkat maka akan menaikkan kinerja karyawan PT. Askes (Persero) Palu sebesar $66.3 \%$ dengan asumsi variabel (X2) tetap.

3. Kompetensi (X2) dengan koefisien regresi 0.421 ini berarti terjadi pengaruh yang positif antara kompetensi dan karyawan PT. Askes (Persero) Palu. Artinya jika kompetensi yang dimiliki pegawai meningkat maka akan menaikkan kinerja karyawan PT. Askes (Persero) Palu sebesar $42.1 \%$ dengan asumsi variabel (X1) tetap.

\section{Pengujian Hipotesis Pertama}

Uji serempak adalah sebuah pengujian untuk mengetahui apakah variabel independen (X) yang diteliti memiliki pengaruh terhadap variabel dependen (Y) berarti semua variabel bebasnya, yakni adversity quotient (X1) dan kompetensi (X2) terhadap kinerja (Y) karyawan PT. Askes (Persero) Palu. Dari tabel diatas terlihat hasil uji determinasi (kehandalan model) memperlihatkan nilai $R$-Square 0,885 atau $88,5 \%$. Hal ini berarti bahwa kemampuan model untuk menjelaskan kinerja karyawan PT. Askes (Persero) Palu sebesar $88,5 \%$ selebihnya dijelaskan oleh di luar model yang diteliti.

Selanjutnya berdasarkan tabel 4.7. dari hasil perhitungan diperoleh $\mathrm{F}$ sig pada taraf nyata $\dot{\alpha}=0,05$ maka diperoleh Sig F $(0.000)<0,05$, dengan demikian dapat dinyatakan bahwa secara serempak semua variabel bebas mempunyai pengaruh yang signifikan terhadap variabel tidak bebas, dalam artian hipotesis pertama yang menyatakan bahwa; adversity quotient dan kompetensi secara serempak berpengaruh signifikan terhadap kinerja karyawan PT. Askes (Persero) Palu, dapat diterima.

\section{Pengujian Hipotesis Kedua}

Variabel adversity quotient, hasil perhitungannya menunjukkan bahwa sig t 0,000 , dengan demikian nilai Sig $\mathrm{t}<0,05$ pada taraf kepercayaan 95\%. Sehingga dapat dinyatakan bahwa varaibel adversity quotient berpengaruh signifikan terhadap kinerja karyawan PT. Askes (Persero) Palu. Dengan demikian maka hipotesis kedua yang menyatakan bahwa; adversity quotient berpengaruh positif dan signifikan terhadap kinerja karyawan PT. Askes (Persero) Palu, dapat diterima.

\section{Pengujian Hipotesis Ketiga}

Variabel kompetensi,

hasil

perhitungannya menunjukkan bahwa sig t 0,000 dengan demikian nilai Sig $\mathrm{t}<0,05$ pada taraf kepercayaan $95 \%$. Sehingga dapat dinyatakan bahwa variabel kompetensi berpengaruh signifikan terhadap kinerja karyawan PT. Askes (Persero) Palu. Dengan demikian maka hipotesis ketiga yang menyatakan bahwa; kompetensi berpengaruh positif dan signifikan terhadap kinerja karyawan PT. Askes (Persero) Palu, dapat diterima.

\section{Pembahasan}

Berdasarkan hasil analisis data yang telah diuraikan sebelumnya, menujukkan bahwa variabel adversity quotient (X1) dan kompetensi (X2) secara bersama-sama berpengaruh signifikan terhadap kinerja (Y) karyawan PT. Askes (Persero) Palu. Hasil tersebut mengindikasikan bahwa adversity quotient (X1) dan kompetensi (X2) dapat meningkatkan kinerja (Y) karyawan PT. Askes (Persero) Palu, hal ini bermakna bahwa hipotesis yang diuraikan sebelumnya sejalan dengan hasil penelitian ini.

Pada setiap diri karyawan telah dibekali dengan beberapa faktor yang mampu menunjang kinerja karyawan itu sendiri. Dari beberapa penelitian, seseorang yang memiliki kinerja baik tidak hanya dikarenakan faktor gen yang membuat seseorang tersebut pintar, cepat menguasai pekerjaan sampai dengan daya tanggap terhadap pekerjaan baru, akan tetapi karyawan yang memiliki kinerja yang baik adalah karyawan yang mampu mengelola faktor internal dan eksternal dengan sangat baik..

Karyawan PT. Askes (Persero) Palu pada umumnya diwajibkan untuk mencapai kinerja sesuai dengan standar yang telah ditetapkan oleh PT. Askes (Persero) Palu, saat penelitian, faktor adversity quotient dan kompetensi akan sangat mempengaruhi kinerja, seperti ketika seorang karyawan melayani seorang yang menggunakan jasa PT. Askes maka karyawan tersebut tidak hanya dituntut untuk dapat menjawab pertanyaan dengan kecerdasan intelektualnya, namun bagaimana dia menyelesaikan pertanyaan dengan jawaban dan sikap yang lugas lebih penting dari faktor kecerdasan tersebut, namun sebagian besar karyawan tersebut tidak akan dapat menyelesaikan masalah tersebut tanpa didukung dengan kompetensi kerja yang mendukung. 


\section{KESIMPULAN}

\section{Kesimpulan}

Berdasarkan hasil penelitian dan pembahasan dengan menggunakan metode analisis regresi berganda, dapat disimpulkan sebagai berikut;

1. Adversity quotient dan kompetensi secara serempak berpengaruh positif terhadap kinerja karyawan PT. Askes (Persero) Palu.

2. Adversity quotient berpengaruh positif dan signifikan terhadap kinerja karyawan PT. Askes (Persero) Palu.

3. Kompetensi berpengaruh positif dan signifikan terhadap kinerja karyawan PT. Askes (Persero) Palu.

\section{SARAN}

Berdasarkan hasil pembahasan pada bab sebelumnya, dapat disarankan hal-hal sebagai berikut;

1. Hendaknya pihak manajemen PT. Askes (Persero) Palu untuk mempertimbangkan pelatihan kecerdasan emosi karyawan yang lebih khusus lagi pelatihan adversity quotient, hal ini dikarenakan variabel inilah yang paling banyak memberikan kontribusi positif terhadap kinerja karyawan PT. Askes (Persero) Palu.

2. Hendaknya pihak manajemen PT. Askes (Persero) Palu secara intensif melakukan evaluasi terhadap kompetensi karyawan sehingga dapat terus terjaga kualitasnya, hal tersebut dapat dilakukan melalui pelatihan internal maupun kerjasama dengan pihak lain yang berkompeten atau melakukan studi banding untuk menambah wawasan, serta memberi kesempatan dan peluang yang sama pada para pegawai untuk mengembangkan diri.

3. Untuk peneliti selanjutnya dapat meneliti pada perusahaan swasta dan pemerintahan untuk mendapatkan pola pengembangan pegawai yang berkaitan dengan adversity quotient dan kompetensi.

\section{DAFTAR PUSTAKA}

Armanu, T. (2005). Hubungan Kepemimpinan, Arikunto, Suharmisi, 2002, Prosedur Penelitian Suatu Pendekatan Praktik, Edisi Revisi Ii, Penerbit Rineka Cipta. Jakarta.

As'ad.2000.Psikologi Industri. Edisi Keempat, Liberty. Yogyakarta.

Azis, A. (2019). Pengaruh Citra Merek Dan Kepuasan Konsumen Terhadap Loyalitas Konsumen Sim Card Telkomsel (Studi Pada Pengguna Sim Card Telkomsel Di Ampana Kota). Jurnal Ekonomi Trend, 7(1), 71-82. Https://Doi.Org/10.31970/Trend.V7i1.174

Asropi.2007. Manajemen Kinerja. Pt. Gramedia Elex Pustaka. Jakarta.

Bary Dan Lodge, 2001, Perilaku Dan Desain Organisasi,Pt. Prehelindo. Jakarta.

Danim, Sudarwan. 2008. Kinerja Staf Dan Organisasi.Pustaka Setia. Bandung.

Fabiola, 2005, Analisis Pengaruh Kecerdasan Intelektual, Kecerdasan Emosi, Dan Kecerdasan Spritual Terhadap Kinerja Karyawan (Studi Kasus Di Hotel Horison Malang), Tesis Tidak Diterbitkan, Universitas Diponegoro. Semarang.

Fianti, 2007, Analisis Pengaruh Motivasi, Kompetensi, Kondisi Kerja Dan Perilaku Kerja Terhadap Kinerja Pegawai Pt. Askes (Persero) Regional $\mathrm{X}$, Tesis Tidak Diterbitkan. Program Pascasarjana Universitas Tadulako. Palu.

Hardwintasari, I. G. A. I.(2017). Hubungan Antara Adversity Quotient, Persepsi Terhadap Kompensasai Dan Kinerja Karyawan Pt. Bank Perkreditan Rakyat (Bpr) Mitra Di Bali.Skripsi.Bali.

I Putu Ari Saputra, Iwayan Bagia Dan I Wayan Suwendra, 2016. Pengaruh Kompetensi Dan Disiplin Kerja Terhadap Kinerja Karyawan. EJurnal Bisma Universitas Pendidikan Ganesha. Jurusan Manajemen. Vol. 4 Tahun 2016.

Imam Ghozali, 2005, Analisis Multivariate Dengan Program Spss, Badan Penerbit Universitas Diponegoro, Semarang.

Ilyas Y, 2001, Kinerja, Teori Penilaian Dan Penelitian. Cetakan Kedua. Pusat Kajian Ekonomi Kesehatan Fkm Ui. Depok.

Laura \& Sunjoyo, (2009).Pengaruh Adversity Quotient Terhadap Kinerja Karyawan: Sebuah Studi Kasus Pada Holiday Inn Bandung. Fakultas Ekonomi Universitas Kristen Maranatha. 


\section{Jumal ERonomi Trend Vol. 08 SNo. 01 Januari - Juni 2020 E-ISSS. 2722-6565}

Kaco, Munira (2006) Pengaruh Kompetensi Dan

Sugiyono. Dr. 2001. Metode Penelitian Administrasi,

Kompensasi Terhadap Kualitas Layanan Suprihanto, 2000, Penilaian Kinerja Dan Pengembangan Kesehatan Masyarakat Miskin Di Puskesmas Karyawan. Edisi Pertama Bpfe, Yogyakarta Kecamatan Palu Barat Kota Palu. Tesis, Supramono, 2005, Statistika. Andi Offset. Yogyakarta. Program Pascasarjana Universitas Tadulako, Supriyanto. 2006. "Meningkatkan Eksistensi Ipi Dalam Palu.

Muchlas, 2000. Manajemen Sumber Daya Manusia. Cetakan Pertama. Erlangga. Jakarta.

Mengembangkan Profesionalisme Pustakawan". Dalam Supriyanto Dan Rimbarawa (Ed.), Aksentuasi Perpustakaan Dan Pustakawan. Ikatan Pustakawan Indonesia Pengurus Daerah Dki Jakarta. Jakarta.

Nawawi, 2002, Manajemen Sumber Daya Manusia: Untuk Yang Kompetitif. Cetakan Pertama. Gadjah Mada University Press. Yogyakarta.

Palan, R. 2007. Competency Management. Teknik Mengimplementasikan Manajemen $S d m$ Berbasis Kompetensi Untuk Meningkatkan Daya Saing Organisasi. Penerjemah: Octa Melia Jalal. Penerbit Ppm. Jakarta.

Prawirosentono, 2003, Kebijakan Kinerja Karyawan. Bpfe. Yogyakarta.

Raharso, S (2004) Competence Based Organization: Penyelenggaraan Antara Kompetensi Individu Dengan Core Competence Organisasi. Jurnal Manajemen Usahawan No. 10/Thn Xxxiii.

Rangkuti, Freddy, 2009, Riset Pemasaran, Penerbit Pt. Gramedia Pustaka Utama. Jakarta.

Ratri, 2009, Hubungan Adversity Quotient (Aq) Dengan Kinerja Karyawan Pada Jurusan Psikoligi Universitas Muhamadiyah Surakarta, Tesis Tidak Diterbitkan, Program Pascasarjana Universitas Muahamadiyah. Surakarta.

Robbins, 2003, Prinsip-Prinsip Perilaku Organisasi, Edisi Kelima, Erlangga. Jakarta.

Scoltz, Paul G. (2000). Adversity Quotient: Mengubah Ancaman Menjadi Peluang: Terjemahan Ridwan Dan Nasir. 2000. Erlangga. Jakarta.

(2004). (Alih Bahasa Hermaya, T.) Adversity Quotient Merubah Hambatan Menjadi Peluang, Pt. Grasindo; Jakarta.

Setiaji, Bambang, 2004. Panduan Riset Dengan Pendekatan Kualitatif, Surakarta: Program Pascasarjana Usm.

Sianipar, 2005, Pengaruh Motivasi Kerja Terhadap Kinerja Karyawan Pt. Dunia Ilmu, Tesis Tidak Diterbitkan, Universitas Airlangga. Surabaya.

Simamora, 2000, Manajemen Sumber Daya Manusia, Edisi Kedua. Bagian Penerbitan Stie Ykpn. Yogyakarta.

Subekti, Asih (2008) Analisis Pengaruh Motivasi Dan Kompetensi Terhadap Kinerja Pegawai Pada Kantor Kantor Cabang Pegadaian Di Propinsi Sulawesi Tengah. Tesis, Program Pascasarjana Universitas Tadulako, Palu. 